\title{
An Interview with David Dabydeen on Literature and Politics
}

\author{
Interviewed by Ruzbeh Babaee \\ University Putra Malaysia, Malaysia
}

Received: -

Accepted: -

Published: 01-07-2016

doi:10.7575/aiac.ijclts.v.4n.3p.73

URL: http://dx.doi.org/10.7575/aiac.ijclts.v.4n.3p.73

Professor David Dabydeen is a Guyanese-born writer, critic and academic at the Centre of Caribbean Studies at the University of Warwick. In 1993 he became Guyana's ambassador at UNESCO and is still a member of their Executive Board. He has been Guyana's ambassador to China since 2010. Professor Dabydeen has also won several international and national prizes such as the Commonwealth Poetry Prize, the Quiller-Couch Prize, and the Hind Rattan (Jewel of India). Among his works are Slave Song (1984), The Intended (1991), Disappearance (1993); and Our Lady of Demerara (2004). He also co-edited The Oxford Companion to Black British History in 2007.

RB $^{1}$ : You are both a writer and a university professor of comparative literature. Do you know yourself first as a writer or a university professor?

DD $^{2}$ : First as a writer. When I was a boy that is basically all I wanted to be. As a teenager I wrote the usual self-pitying stuff and, at 16 or 17, I attempted a novel in verse, inspired by some story in the Bible, I forgotten which; but gave up after a couple of pages. Why want to be a writer? I don't know. In my youth in Guyana I never encountered a writer. I think it must have been youthful aspiration to emulate the writers of Nancy Drew and Hardy Boys novels, which were standard childhood fare in Guyana. Also, since I come from a large family, it must have been the regular escape to the New Amsterdam public library to be alone, and whilst there( the place was usually empty), discovering books in the Ladybird series on great scientists, great politicians etc. I distinctly remember reading about Benjamin Franklin, Madame Curie, Alexander the Great, and others, at the age of nine or ten. There were also the odd books on Greek myths, lavishly illustrated for children. The story of Andromeda chained and naked and threatened by a monster, before being saved by Perseus, awakened unfamiliar boyish erotic feelings... perhaps not 'unfamiliar '( I was 8 or 9 ) but certainly the first time a book had aroused such feelings. When I was about 11 or 12 I came across V.S. Naipaul's MIGUEL STREET and was awed by how it made our lives in Guyana so familiar. It was set in Trinidad but the characters lived down my street. A great contrast to the Andromeda story which was exotic and erotic as opposed to the familiar lives of ordinary folk described by Naipaul.

Being an academic has also been important to my writing. Firstly, you get a lot of time to read and discuss books with very bright students. Teaching in seminar groups has been amazingly exciting at times, and that intellectual excitement, sensuous in intensity, inspires the act of writing. I used to teach MA courses on Black British Literature and on Literature and Slavery. Certainly, Olaudah Equiano's autobiography in 1789, which I read multiple times for teaching purposes, left an impact on my writing, which is dotted with 'Equiano' figures ( people who moved from deprivation to the craft of writing, through cunning and an inclination for mischief mostly). Secondly, as an academic, you are exposed to theory, which can fertilised your writing and give it a 'metaphysical' content. Overexposure leads to didacticism, which I am sure my writing suffers from. As Derek Walcott says, you shouldn't "put Descartes before the horse." Most importantly, being an academic pays the bills, so whilst hunger has provoked a lot of writers, I preferred to have a house rather than a hovel. Growing up in Guyana was to exist in relative lack of material things. Many years ago I met Maya Angelou, she had kindly invited me to her house, and she had cooked a lovely Southern meal. She said: "I drive a Cadillac. I don't do bicycles, which were my youth. And I eat meat, because all I had as a child was garden vegetables'. I appreciated her extravagance, though deep down she was a kindly person, and generous.

RB: You are also a politician. In 2010 you were appointed as Guyana's Ambassador in China. How have you proved yourself as a politician?

DD: I don't belong to any political party in Guyana, but I enjoyed a close friendship with Cheddi and Janet Jagan. Cheddi had been cheated out of office as a result of the CIA and the British Government, in the 1960s, because he was a committed man of the left. In 1984, when I was appointed to Warwick University, I invited Cheddi to lecture there. He had no money, so the University and a travel agent friend, Vino Patel, were persuaded to provide his economy ticket and accommodation whilst at Warwick. We treated him as the true President of Guyana. All the national elections had been fiddled, and he was kept out of office for decades. Warwick offered him a platform, when other places thought of him as a 'has been'. He visited about five times, then in 1992, the Berlin Wall having fallen and the Cold war ended, the Americans allowed us to have free and fair elections, supervised by President Carter and Cheddi Jagan won and became

\footnotetext{
${ }^{1}$ Ruzbeh Babaee

2 David Dabydeen
} 
President of Guyana. I was his regular houseguest from 1992 until 1997 when he died. He taught me more about how colonialism behaved than any textbook. He had lived through the colonial period and was jailed by the British in 1953. All his life was dedicated to the betterment of the poor: he was fiercely concerned with reducing and eliminating poverty. In return for his great hospitality, all I could do was to edit and publish some of his political speeches. He also asked me to be his Ambassador at Large and to sit on the UNESCO Executive Board representing Guyana. He had no money, since he inherited a bankrupt country in 1992, so it was an amazing honour to serve him pro bono. One day I will write something more extensive about him... one of the stories he told me was about Fidel Castro. The two of them were friends and political comrades in the late 50s and early 60s. It was Cuba who supplied us with food in the early 1960s when the CIA formented strikes and shortages in Guyana. Castro, however, needed allies in the region, against American embargo, so when Cheddi was manoeuvred out of Office, Castro started to court the friendship of our new autocratic Prime Minister, Forbes Burnham, and more or less dropped his relationship with Cheddi. I learn from this that politics trumps decency; that politicians by and large are opportunists. Learning this first hand from a great and ethical politician like Cheddi Jagan was more powerful than learning this from textbooks.

As to Janet Jagan, his wife, who, when he died, was elected President in our national elections, with an enhanced vote, she was an astonishingly generous host. My role was to edit and publish her short stories for children. She was a bit lonely in Guyana, in terms of only a few people to share her passion for the arts, so whenever I showed up, a bottle of wine was uncorked, or better still, a bottle of Bailey's Irish Cream( we had a local equivalent). She too had been jailed by the British in 1953, so, again, I learnt from her intimate details of Guyana's struggle for independence, and the callousness of politicians ( Forbes Burnham had attempted to murder her in the 1964 but his bomb went off in the wrong place in the Party's Headquarters, killing a young activist instead, Michel Forde. Janet suffered from minor injuries.)

As to Walter Rodney, Guyana's internationally renowned historian, assassinated by Forbes Burnham and the State apparatus in 1980( the International Commission of Enquiry into his death was issued to Guyana's Parliament last month), it was an enlightened decision on the part of the University of Warwick to set up an annual Memorial Lecture . The Walter Rodney lecture has been given, since 1985, by some of our leading Caribbean scholars, like Hilary Beckles, Carolyn Cooper, Harold Goulbourne, Michael Gilkes, Clem Seecharan, Ken Ramchand, Verene Shepherd and others.

I don't think I have proved myself as a politician in any concrete way. My only possible 'political' act was, in 20122013 lobbying the Government of Guyana vigorously and regularly to set up an International Commission of Enquiry into the death of Walter Rodney. I took full advantage of my friendship with the then President, Donald Ramotar, who was readily sympathetic to Pat Rodney's written request for such an Inquiry( Walter's widow). As a member of the Walter Rodney Foundation's Advisory Group, I liaised with Pat Rodney and in 2013 the Government of Guyana agreed to set up the Commission. I don't think this was a 'political' act on my part, merely the obligation I felt to Walter Rodney, a fellow academic whose books were monumental.

\section{RB: How do you define politics?}

DD: In a small underdeveloped or developing country, politics normally is about the acquisition of power over state resources for the benefit of family and friends. Idealism goes out of the window as soon as the politician assumes Office; the struggle then is for survival and continuation of Office, so very little good gets done, political energy being spent on maintaining and expanding the arena of privilege. Exceptions are rare, people like CheddiJagan, Nelson Mandela...Cheddi was famous for his frugal lifestyle. He died intestate, owning no property. He never stole from the national treasury, rare for a politician from the developing world. Had Rodney lived, he would have been a leader of exemplary ethics. I should add my admiration for a previous, undemocratically elected President of Guyana, Desmond oyte, who, long before the Rio Summit and long before 'Climate Change' was topical, bequeathed a million acres of Guyana's rainforest to the Commonwealth, for the study of sustainable development (the Iwokrama Project). This was in 1989. It was an act of rare vision by a Caribbean politician. So, politicians like Hoyte might have been elected by crookery, but can prove to be significant and visionary leaders. I enjoyed cordial relations with him, when he was President (1985-1992) as well as when he was Leader of the Opposition, again based on books. We talked a lot about Egbert Martin, the first Guyanese poet and short story writer (19th century), and about the Guyana Prize for Literature which he had instituted in 1987, in the hope of bolstering the literary and intellectual life of Guyana and its Diaspora. He had a wonderful library, and he cared deeply for literary achievement. We talked little about party politics, except about the sharing of political power and the Mandela Rainbow ideal. Towards the end of his life he was all for power sharing, though he had enough integrity to worry about where oppositional ideas would come from if we were all in alliance.

\section{RB: Do your political affairs affect your creative writing?}

DD: There is no direct link, though I have written about the dereliction of Guyana under the autocratic rule of Forbes Burnham. My new novel-in-progress, set partly in China, is provoked by the unimaginable cruelty imposed on the people by the Emperors and their warlords. So, politics breeds in me a despair which can stimulate writing. One of the great disappointments, living in Britain, was Tony Blair's loss of idealism ( he seemed abundantly idealistic, which is why people voted him into Office in 1992) and the lies he told about Iraq's military capacity to justify a hideous and bloody invasion of Iraq. On the other hand, in Britain, there were politicians like Jo Cox, who was visionary and full of promise ( she was murdered recently), and who made all of us feel hopeful and glad to be alive. If only we had a handful of such politicians in Guyana! I am privileged to enjoy a long-standing friendship with Clare Short, the former Labour politician whose heart is as big as Mount Kilimanjaro. 
RB: You have often depicted Guyanese characters and settings in your fiction such as Disappearance (1993), The Counting House (1996), and Our Lady of Demerara (2004). Does it mean that you still live in your past? and that you know yourself devoted to your homeland?

DD: I do live in the past, in that my childhood in Guyana left indelible memories of family and friends and village landscape. Especially the creole language we spoke at home, and the creative tension with the 'proper' English we spoke at school. The slippages between the two are fascinating, with potential for comedy and pathos. The vigour of creole is always with me.

Leaving Guyana as a boy was exciting (the prospect of adventure) but then proved to be lonely and hurtful, since I was never settled in England. On the one hand, England was a world of books but at the same time a world of grunting and guttural 'skinheads' daubing racist slogans on walls and threatening to assault immigrants. London has changed profoundly since the 60's and 70's, it is now a diverse space, enriched by waves of immigrants from the Commonwealth and from Europe. There is still a strong undercurrent of racial hostility, but more in the north of England, hence the recent vote to leave the European Community. Many in the north of England have not got accustomed to the loss of Empire and the new order of the free movement of goods and people. This hostility is at the ideological level, and contradictory, because on a day to day level, people are, by and large, decent to each other, irrespective of ethnicity. London is different; it is run by people of immigrant backgrounds: nurses, doctors, builders, hotel and retail staff, care workers. I am astonished at how much has changed, and I am excited to be living in London. The creative energy of the city is palpable, and the diversity of people is inspiring. I no longer feel culturally or physically threatened, as in the 1960's and 1970's. In other words, I feel London is home, but so is Guyana. I return to Guyana at least once a year, to renew my sense of the past, to be refreshed by creole language and creole ways, and to be awed and terrified by the rainforest. I also keep writing about Guyana partly out of a sense of obligation to the place. We only have a handful of writers, so I feel it is important to write about the place. Guyana came into modern being, in a sense, through literature: I am thinking specifically of Walter Raleigh's DISCOVERIE OF GUIANA (1596), the first text about us.

RB: Why do you often depict historical tensions and challenge traditional cultural representations of the slave in your novels?

DD: Guyanese history, in relation to contact with Europe, is stark: the decimation of indigenous people, the enslavement of Africans, the system of Indian indentureship. It is stark in terms of the immensity of suffering, and the sheer injustices of colonial rule. Yet, we became acquainted with Samuel Johnson's DICTIONARY and the magical properties of the English language; with the lyricism and storytelling of the Bible, of Shakespeare, of Victorian poetry. These new texts supplemented the ones we brought from Africa and India ( the KORAN, the RAMAYANA) . Ancient and living Carib, Arawak and other Amerindian stories fertilised the situation. We rewrote and reimagined our inheritance, hence Walcott, Naipaul, Jean Rhys, Pauline Melville, Grace Nichols, John Agard, and a host of others. I write about the injustice (historical, but also self-inflicted in our postcolonial condition) but more about the urge to creativity and expression that emerged from being on the margins; the fierce resolve to become educated, literate, creative, venturing beyond boundaries. Our postcolonial politicians may have failed us repeatedly, but I am forever astonished at how resilient Guyanese are. When I visit parts of India, parts of China, the nature of poverty there is brutal and overwhelming. We don't have that level of deprivation, because we have created the means of survival and the prospect of abundance, whether on the plate or on the page.

RB: Do you believe that there is any nation on earth that enjoys true freedom and independence?

DD: I don't know what true freedom or independence mean, we are all constrained and liberated and catapulted into creativity by being with each other. However, I recall what Walcott said about slavery: that the enslaved African being herded to the cane fields would have seen something sensationally beautiful along the way, given how lush Caribbean landscapes are. A hummingbird or kiskadee or blue-saki or brightly coloured viper... Walcott said that such encounters with beauty were moments of freedom which could only be partially understood, partially described, because they also contained the seeds of tragedy and terror. If you venture into Guyana's rainforest, you will experience the sublime which contain elemental terror and a tragic sense of how life is constantly being destroyed and remade and destroyed by tooth and claw.

\section{References}

Babaee, R. (2016). Translation and Creative Writing: An Interview with Professor Margaret Rogers. International Journal of Comparative Literature and Translation Studies, 4(1).

Jagan,Ch. (1966). The West On Trial: My Fight For Guyana's Freedom. London. Michael Joseph Ltd

Rodney, W. (1972). How Europe Underdeveloped Africa. Bogle-L'ouverture Publications

Seecharan, C. (2005). Sweetening Bitter Sugar: Jock Campbell, The Booker Reformer In British Guiana, $1934-1966$.

Ian Randle Publishers

Harris, W. (1960). Palace Of The Peacock. Faber \& Faber.

Melville, P. (1999). The Ventriloquist's Tale. Bloomsbury USA

Agard, J. (1982). Man To Pan. Casa De Las Américas. 